\title{
New insights into volatile-rich mantle metasomatism at the Bultfontein diamond mine, Kimberley, South Africa
}

\author{
Charlotte G. Jackson ${ }^{\mathbf{1}}$ and Sally A. Gibson ${ }^{\mathbf{1}}$ \\ ${ }^{1}$ University of Cambridge, Cambridge, United Kingdom, cj340@cam.ac.uk, sally@esc.cam.ac.uk
}

\section{Introduction}

Metasomatised regions of the sub-continental lithospheric mantle potentially represent a large volatile reservoir. Nevertheless, the mechanisms involved in the storage and upward transport of volatiles (such as $\mathrm{C}$ and $\mathrm{S}$ ) from the convecting mantle and/or subducting slabs, are poorly understood. We have carried out a systematic micro-analytical study on a suite of sulfide-rich mantle peridotites from the Kaapvaal Craton. The studied xenoliths are from the Bultfontein diamond mine, Kimberley and exhibit a range of trace-element enrichment processes, from solely cryptic to modally metasomatised (Kramers et al. 1983). We have chosen this suite because the olivines have the same mantle normalised REE pattern with varying levels of enrichment. We investigate the possibility that the suite represents the progressive stages of reactive percolation of a volatile-rich small-fraction metasomatic agent during ascent through the subcratonic lithospheric mantle.

\section{Petrographic description}

Our study focusses on two key xenoliths that appear to represent the two endmembers of reactive percolation of a metasomatic agent: one is a cryptically metasomatised harzburgite that has had no modal mineralogical change (BD1676) and the other represents the modally metasomatised endmember (BD3067).

BD1676 has $60 \%$ olivine, $35 \%$ orthopyroxene and $5 \%$ fingerprint spinel/augite intergrowths, i.e. a decompression product of garnet. BD3067 contains large $(6 \mathrm{~mm})$ porphyroclastic olivines in a matrix of small polygonal olivine neoblasts. The spectacular feature of this xenolith is a large, trichotomous branching clinopyroxene-rich vein, measuring 45 $\mathrm{mm}$ at it's widest point in hand specimen. This vein is shown in the QEMSCAN image in Figure 1. Branch terminations and regions of clinopyroxene crystallisation away from the main vein are associated with phlogopite crystallisation. There are also large zircons, up to $5 \mathrm{~mm}$ diameter, within the vein. Additionally, large interstitial Fe-Ni sulfides occur amongst the olivine neoblasts.

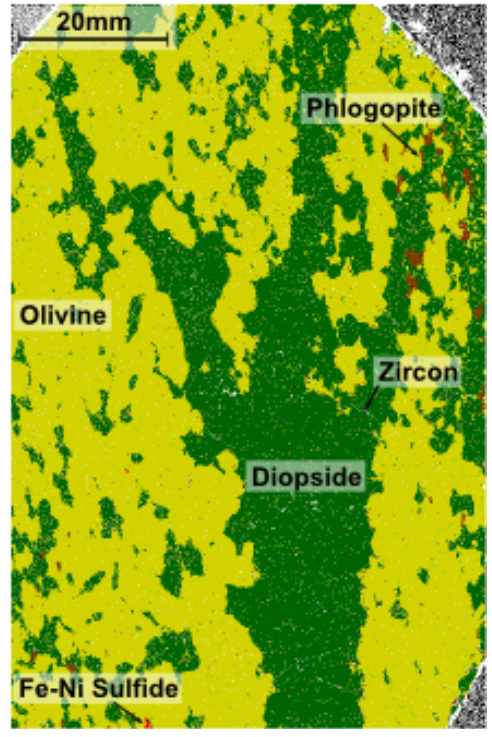

Figure 1: QEMSCAN image of xenolith BD3067

\section{Analytical Results}

\section{Olivine}

The olivine in cryptically metasomatised BD1676 has a forsterite content typical of sub-cratonic mantle $\left(\mathrm{FO}_{92}-\mathrm{FO}_{93}\right)$. In contrast, both the porphyroclasts and neoblasts in BD3067 have had significant Fe-enrichement $\left(\mathrm{Fo}_{88}\right)$. The latter are also enriched in $\mathrm{MnO}(0.13-0.19 \mathrm{wt} . \%)$ relative to the olivines in $\mathrm{BD} 1676(\mathrm{MnO}=0.09-0.13 \mathrm{wt} . \%)$. Both olivine populations in BD3067 are homogeneous in all the major elements but the largest porphryoclasts show Ni-variation in core to rim profiles (Figure 2). The olivines in BD3067 are all Ni-depleted (0.18-0.22 wt. \% NiO) compared to those from BD1676 (>0.4 wt. \% NiO). In BD3067, only the largest crystals ( $>4 \mathrm{~mm}$ diameter) are unequilibrated. Experimental work has shown that the diffusion coefficients for $\mathrm{Fe}-\mathrm{Mg}, \mathrm{Mn}$ and $\mathrm{Ni}$ are very similar at all conditions tested ( $T$ and $f_{2}$, and $P$; Petry et al. 2004; Holzapfel et al. 2007). The olivines are all otherwise 
homogeneous in $\mathrm{Fe}, \mathrm{Mg}$ and $\mathrm{Mn}$, we therefore conclude that differing diffusivities of the elements in olivine is not responsible for the Ni variation.

(a)

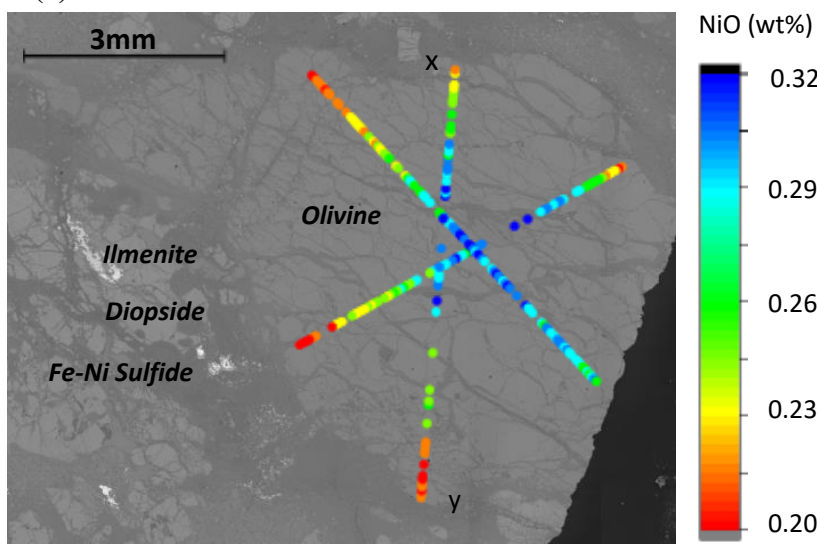

(b)

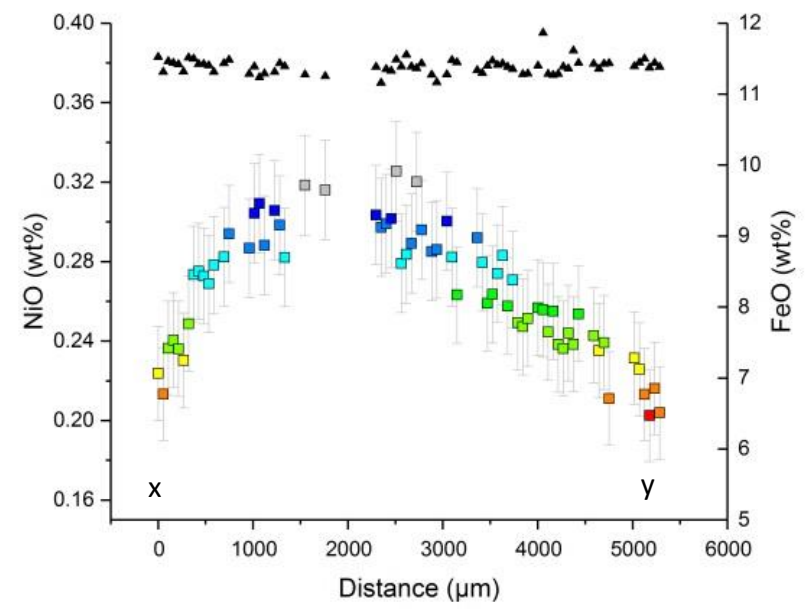

Figure 2: $\mathrm{NiO}$ variation in a large unequilibrated olivine from BD3067. (a) BSE image with NiO profiles overlain. (b) Example of profiles marked $\mathrm{x}-\mathrm{y}$ in (a) that shows the asymmetry in core-rim variation of $\mathrm{NiO}$. Black triangles show the $\mathrm{FeO}$ concentration along the same profile.

The $\mathrm{Ni} / \mathrm{Fe}$ ratio in the olivines ranges from $0.016-0.019$. This is very low for mantle olivines, but is within the range of the olivines found as inclusions in diamonds (Tomlinson et al., 2005). These workers attributed the anomalously low $\mathrm{Ni} / \mathrm{Fe}$ ratios to olivine crystallisation in the presence of Nirich sulfides. The latter are one of the most common mineral phases found as inclusions in peridotitic diamonds and, since Ni partitions preferentially into sulfides over olivine, the olivine crystallising in the presence of sulfides is expected to have a lower Ni content.

\section{Sulfides}

Modally metasomatised xenolith BD3067 contains a high modal proportion of Fe-Ni sulfides. They are interstitial and associated with phlogopite and carbonate. These features imply that these are metasomatic sulfides rather than primary mantle sulfides. The sulfides are heavily serpentinised and extremely heterogeneous in terms of their compositions. The Ni-rich regions of the sulfides have $>35$ wt $\% \mathrm{NiS}$ and are in equilibrium with the Ni-depleted olivines $\left(\mathrm{K}_{\mathrm{D}}=30\right.$; Fleet and MacRae 1988).

\section{Interpretations}

The absence of orthopyroxene in the modally metasomatised xenolith BD3067 implies that the precursor peridotite (harzburgite) may have reacted with a silica-undersaturated melt. We suggest that the suite of xenoliths represents the progression of the reaction:

$\mathrm{Mg}$-carbonatitic melt + orthopyroxene $\rightarrow$ olivine + clinopyroxene $+\mathrm{CO}_{2}$ fluid $\quad$ (Dalton and Wood 1993)

Recent experimental work by Gervasoni et al. (2017) has confirmed that a wehrlitic assemblage is produced by the reaction of a carbonatitic melt and fertile peridotite and that the ratio of pyroxene to olivine is reflective of the melt:rock ratio. High Mg\# in the clinopyroxenes (90-93) support this interpretation.

The presence of metasomatic Fe-Ni sulfides in BD3067 implies that the Bultfontein mantle has experienced an interaction with a sulfur-rich fluid. We suggest that preferential partitioning of Ni into the sulfide caused the observed Ni-depletion of olivine in the host mantle, (Figure 3). While the olivine neoblasts have reached $\mathrm{Ni}$ equilibrium with the sulfides the largest porphyroclasts have not. Our calculations of Ni diffusivity in olivine suggest that the S-rich infiltration event occurred within 1 Myr of the eruption of the 84 Ma Bultfontein kimberlite (Figure 4). It is unclear whether the S-rich 
metasomatism was in conjunction with the carbonatitic metasomatism, or at a later stage. Our findings are consistent with Giuliani et al. (2013) who identified multiple stages of kimberlite melt evolution, two of which include an alkali-carbonate melt and an immiscible sulfide liquid, at Bulfontein.

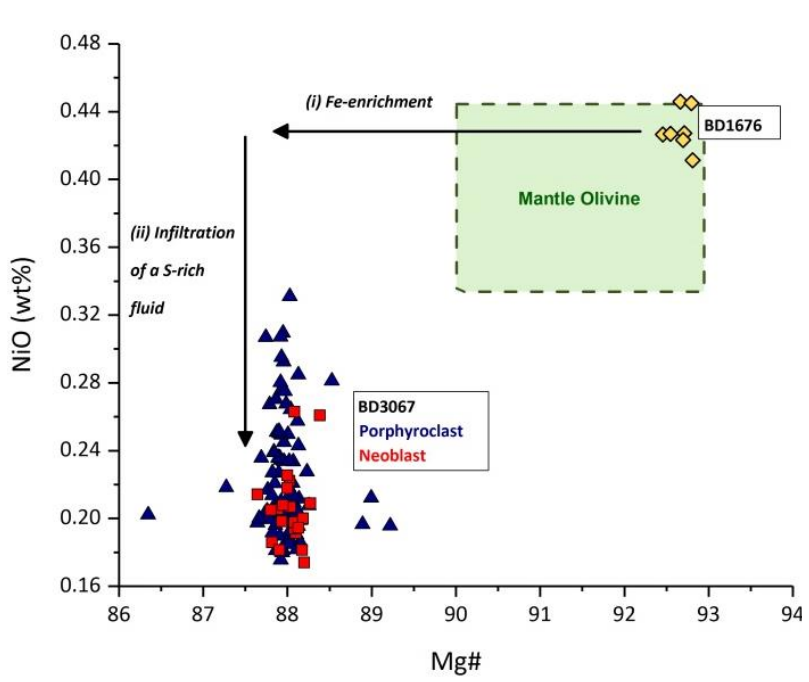

Figure 3: Olivine Mg\# vs. $\mathrm{NiO}$ showing the effect of (i) Fe-enrichment by a metasomatic agent and (ii) the infiltration of a sulfur-rich fluid.

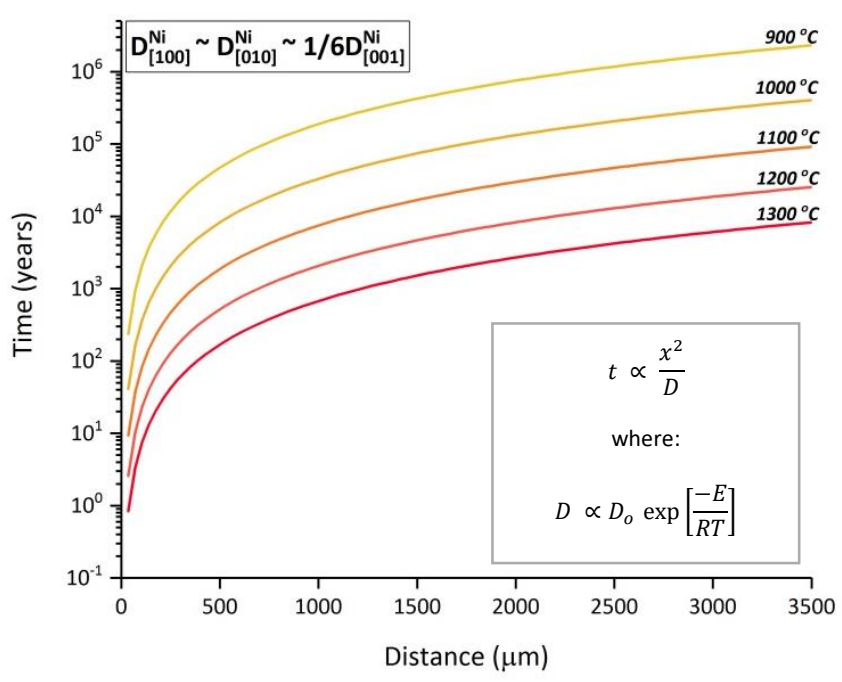

Figure 4: Diffusion timescales for $\mathrm{Ni}$ in olivine in the slowest direction [100] and [010] over a range of temperatures. The fastest direction [001] is roughly equal to 6 times the slowest diffusion timescales (Petry et al. 2004)

\section{Conclusions}

The Bultfontein xenoliths offer a rare insight into the mantle enrichment processes that accompany kimberlite activity. We conclude that at least two different phases of volatile-rich mantle metasomatism affected the southern Kaapvaal craton immediately prior to kimberlite emplacement at $84 \mathrm{Ma}$. These involve (i) reactive percolation of a silica-undersaturated carbonatitic melt that transformed primary enstatite to diopside and the formation of olivine neoblasts; and (ii) the infiltration of a S-rich fluid. Furthermore, the abundance of metasomatic Ni-sulfides at Bulfontein highlights the prevalance of sulfur transport through the sub-cratonic mantle, and the capacity of ancient sub-continental lithosphere to store volatiles.

\section{References}

Dalton JA, Wood BJ (1993) The compositions of primary carbonate melts and their evolution through wallrock reaction in the mantle. Earth Planet Sci Lett 119:511-525. doi: 10.1016/0012821X(93)90059-I

Fleet ME, MacRae ND (1988) Partition of Ni between olivine and sulfide: equilibria with sulfideoxide liquids. Contrib Mineral Petrol 100:462-469. doi: 10.1007/BF00371375

Gervasoni F, Klemme S, Rohrbach A, et al (2017) Experimental constraints on mantle metasomatism caused by silicate and carbonate melts. Lithos 282-283:173-186. doi: 10.1016/j.lithos.2017.03.004

Giuliani A, Kamenetsky VS, Kendrick MA, et al (2013) Oxide, sulphide and carbonate minerals in a mantle polymict breccia: Metasomatism by proto-kimberlite magmas, and relationship to the kimberlite megacrystic suite. Chem Geol 353:4-18. doi: 10.1016/j.chemgeo.2012.09.025

Holzapfel C, Chakraborty S, Rubie DC, Frost DJ (2007) Effect of pressure on $\mathrm{Fe}-\mathrm{Mg}$, $\mathrm{Ni}$ and $\mathrm{Mn}$ diffusion in (FexMg1-x)2SiO4 olivine. Phys Earth Planet Inter 162:186-198. doi: 10.1016/j.pepi.2007.04.009

Kramers JD, Roddick JCM, Dawson JB (1983) Trace element and isotope studies on veined, metasomatic and "MARID" xenoliths from Bultfontein, South Africa. Earth Planet Sci Lett 65:90106. doi: 10.1016/0012-821X(83)90192-9

Petry C, Chakraborty S, Palme H (2004) Experimental determination of Ni diffusion coefficients in olivine and their dependence on temperature, composition, oxygen fugacity, and crystallographic orientation. Geochim Cosmochim Acta 68:4179-4188. doi: 10.1016/j.gca.2004.02.024 